\title{
IMPLEMENTASI ALGORITMA SUPPORT VECTOR MACHINE (SVM) DALAM MEMPREDIKSI HARGA SAHAM PT. GARUDA INDONESIA TBK
}

\author{
Ratih Febrilia Tri Wulandari ${ }^{1}$, Dian Anubhakti2 ${ }^{2 *}$ \\ 1,2, Fakultas Teknologi Informasi, Sistem Informasi, Universitas Budi Luhur, Jakarta, Indonesia \\ Email: ${ }^{1} 1712530151 @$ student.budiluhur.ac.id, ${ }^{2 *}$ dian.anubhakti@budiluhur.ac.id \\ (*: coressponding author)
}

\begin{abstract}
Abstrak-Saham adalah suatu instrument investasi yang banyak diminati oleh penanam modal atau investor dan terkenal di pasar keuangan karena memiliki tingkat keuntungan yang menarik. Di Indonesia, terdapat beberapa perusahaaan yang ada di pasar modal, salah satunya PT. Garuda Indonesia, Tbk. Badan Usaha Milik Negara (BUMN) yang bergerak di bidang jasa layanan transportasi udara yaitu PT. Garuda Indonesia, Tbk dimana Pemerintah Indonesia memiliki saham sebesar $60.53 \%$. Investasi saham memiliki prinsip high risk high return, maka investor perlu melakukan analisa sebelum membeli saham dengan pendekatan fundamental dan teknikal. Untuk mendapatkan keuntungan, investor perlu mengamati perubahan harga saham dari waktu ke waktu (time series) dan resiko yang bisa terjadi seperti turunnya harga dan terjadinya likuidasi pada perusahaan. Tren pergerakan saham dipengaruhi oleh beberapa faktor yaitu laju inflasi, suku bunga deposito, laba perusahaan, keuangan perusahaan, dan strategi pemasaran. Pergerakan saham cenderung bersifat non linier, sehingga diperlukan model prediksi saham yang akurat untuk mengambil keputusan, salah satunya yaitu menggunakan Support Vector Machine (SVM). Algoritma SVM tidak memiliki masalah overfitting dan dapat menentukan model otomatis. Hal ini adalah dasar penelitian ini menggunakan algoritma SVM dalam melakukan prediksi harga saham PT.Garuda Indonesia, Tbk dengan hasil akhir berupa nilai akurasi prediksi harga saham. Data yang digunakan adalah historical harga saham harian sejak tanggal 18 Maret 2019 hingga 23 April 2021. Penelitian ini menunjukkan bahwa menggunakan metode SVM mampu memprediksi harga dengan nilai akurasi prediksi sebesar 0.545 .
\end{abstract}

Kata Kunci: Saham, Investor, Prediksi, SVM, Harga

\begin{abstract}
Stock is an investment instrument which has a great demand by investors and well known in the financial market because it has an attractive profit rate. In Indonesia, there are several companies engaged in the capital market, one of them is PT. Garuda Indonesia, Tbk. PT. Garuda Indonesia, Tbk is a State-Owned Enterprise of Indonesia (Indonesian: Badan Usaha Milik Negara (BUMN)) which is engaged in air transportation services with a share ownership of $60.53 \%$ by the Government of Indonesia. Stock investment has the high risk high return theory, so that the investors need to analyze before buying the shares with a fundamental and technical approach. To get a profit, the investors need to pay attention to the changes of stock prices from time to time (time series) and the risks that can occur such as the drop prices (capital loss) and the occurrence of liquidation in the companies which issued the shares. The stock price changes are influenced by several factors, such as the inflation rate, deposit interest rates, company profits, company finances, and marketing strategies. Stock movements tend to be non-linear, so it need an accurate stock prediction model to make the decisions, one of them uses the Support Vector Machine (SVM). The SVM algorithm has no overfitting problems and can define the model automatically. This is the basis for this research using the SVM algorithm method in predicting the stock price of PT. Garuda Indonesia, Tbk with the final result in the form of stock price prediction accuracy values. The data used is the daily stock prices history from March 18, 2019 to April 23, 2021. This research shows that using the SVM method is able to predict the prices with a prediction accuracy value of 0.545 .
\end{abstract}

Keyword: Stock, Investor, Prediction, SVM, Price

\section{PENDAHULUAN}

Saham adalah suatu instrument investasi yang banyak diminati penanam modal dan terkenal di pasar keuangan karena memiliki tingkat keuntungan yang menarik. Saham menjadi bukti penyertaan modal, sehingga dapat melakukan klaim terhadap pendapatan dan aset perusahaan serta menghadiri Rapat Umum Pemegang Saham (RUPS) [1]. Di Indonesia terdapat beberapa perusahaaan yang bergerak di pasar modal, salah satunya PT. Garuda Indonesia, Tbk. PT. Garuda Indonesia, Tbk merupakan Badan Usaha Milik Negara (BUMN) yang bergerak di bidang jasa layanan transportasi udara dengan kepemilikan saham sebesar 60.53\% oleh Pemerintah Indonesia [2]. Investasi saham memiliki prinsip high risk high return di mana selain dapat memberikan keuntungan yang tinggi, investasi saham juga dapat memberikan resiko yang tinggi. Hal ini yang menjadi pertimbangan para investor untuk melakukan analisis terlebih dahulu sebelum membeli saham. Terdapat dua analisis yang biasa digunakan dalam investasi saham yaitu analisis fundamental dan teknikal [3]. Analisis fundamental adalah analisis yang dilakukan berdasarkan pada kondisi perusahaan baik di masa terdahulu dan kemungkinan yang terjadi di masa mendatang dalam kaitan untuk memprediksi harga saham dengan menggunakan informasi dari berita ataupun laporan keuangan perusahaan. Kemudian, analisa teknikal dilakukan berdasarkan pada pergerakan harga saham di periode 
sebelumnya [4]. Memaksimalkan return dan meminimalkan resiko yang didapat merupakan tujuan utama dari investasi saham. Pembagian dividen merupakan salah satu return kepemilikan saham. Selain itu, return saham dapat berupa hasil jual beli atau transaksi saham yang memiliki potensi keuntungan dan kerugian karena harga jual yang berbeda dari harga beli [5]. Mendapatkan keuntungan merupakan harapan setiap investor, namun hal ini bergantung pada harga setiap saham yang berubah dari waktu ke waktu yang disebut data runtun waktu (time series). Mengingat setiap bidang investasi memiliki resiko, maka hal ini juga berlaku ketika melakukan pembelian saham. Contoh resiko yang terjadi ketika investasi di bidang saham salah satunya ialah turunnya harga dan perusahaan yang terlikuidasi. Oleh karena itu, meminimalkan resiko-resiko tersebut, para investor perlu melakukan analisis data harga saham setiap saat (time series) dengan aktivitas tinggi [6].

Perubahan harga saham bisa terjadi begitu cepat. Hal ini disebabkan oleh penilaian singkat dari para investor berdasarkan beberapa faktor. Berikut faktor yang mempengaruhi dalam perubahan harga saham adalah laju inflasi, suku bunga deposito, laba perusahaan, keuangan perusahaan, dan strategi pemasaran [7].Prediksi harga saham berguna untuk mengetahui alur investasi di masa mendatang, sehingga para investor dapat memperoleh keuntungan. Investor dapat mengetahui alur investasi dengan melihat perubahan harga saham dari setiap saat [6]. Mengingat pergerakan saham penuh dinamika yang mudah berubah, maka pemilik saham harus mampu membuat keputusan terkait waktu yang tepat untuk menjual atau mempertahankan saham. Pergerakan saham cenderung bersifat non linier, maka para investor memerlukan suatu metode untuk melakukan monitoring prediksi pergerakan harga saham yang akurat, dimana informasi ini dapat digunakan dalam pengambilan keputusan. Hal ini yang menyebabkan prediksi perubahan harga saham menjadi topik utama di kalangan investor [8].

Machine learning merupakan metode akurat yang dapat digunakan dalam melakukan prediksi harga saham. Machine learning merupakan komputer atau program memiliki kecerdasan untuk mengolah data yang berguna untuk proses pembelajaran dan menjadi bahan pertimbangan dalam mengambil keputusan serta menyelesaikan masalah [9]. Saham dikelompokkan menjadi non-stationary time series dan terdapat beberapa teknik mulai dikembangkan untuk memprediksi pergerakan harga saham, Support Vector Machine (SVM) adalah salah satunya. Teknik SVM banyak digunakan oleh investor untuk memprediksi pregerakan indeks harga saham [10].

Pada tahun 1992, Vapnik memperkenalkan metode SVM. Vapnik memperkenalkan sebagai konsep yang unggul di bidang pattern recognition yang memiliki dua kategori, Support Vector Machine Classification dan Support Vector Machine Regression. Algoritma SVM tidak memiliki masalah overfittin dan dapat menentukan model otomatis. Kyong-jae juga melakukan penelitian pada metode SVM dan diketahui bahwa metode SVM mampu mengurangi adanya kesalahan klasifikasi dan penyimpangan data training [8]. Support Vector Machine (SVM) adalah salah satu metode klasifikasi yang bertujuan untuk menemukan hyperplane terbaik yang memisahkan dua buah kelas pada input space. SVM memiliki prinsip dasar yaitu linier classifier dan dikembangkan agar dapat berkerja pada masalah non linier dengan memasukan karnel trick pada ruang kerja berdimensi tinggi [11].

Terdapat beberapa penelitian mengenai prediksi harga saham menggunakan beberapa model algoritma. [6] Melakukan penelitian bertujuan untuk menganalisa prediksi harga saham PT. Antm.JK menggunakan metode SVM. Dari penelitian tersebut, diperoleh hasil bahwa harga saham PT. Antm.JK memiliki nilai terendah RMSE sebesar 10.495. Penelitian menggunakan metode algoritma SVM dan kernel RBF untuk memprediksi harga saham PT. Telekomunikasi Indonesia. Hasil yang diperoleh yaitu tingkat akurasi dengan nilai 0.9641 dan dengan nilai RMSE 0.0923. Sebagai perbandingan, algoritma K-Nearest Neighbors (KNN) juga digunakan oleh 8 pada penelitian ini dan diperoleh hasil bahwa tingkat akurasi dengan nilai 0.945 dan RMSE dengan nilai 0.1161. Dari hasil kedua algoritma tersebut bahwa KNN dengan error yang lebih tinggi dan ketepatan yang dibawah SVM [8].

Selain itu, terdapat penelitian lain terkait komparasi SVM dan Neural Network yang digunakan oleh [7] yang bertujuan untuk memperoleh tingkat akurasi prediksi tertinggi harga saham. Hasil diperoleh adalah nilai akurasi prediksi menggunakan model Neural Network sebesar 0.505 +/- 0.009 (mikro 503) dan model Support Vector Machine (SVM) sebesar 0.477 +- 0.008 (mikro 0.477).

Berdasarkan pemaparan di atas terkait nilai akurasi prediksi harga saham menggunakan metode algoritma SVM, maka peneliti ingin mengetahui secara jelas terkait tren harga saham yang dimiliki oleh PT. Garuda Indonesia, Tbk. Dalam melakukan tulisan ini digunakan algoritma SVM untuk melakukan harga prediksi pada saham PT.Garuda Indonesia, Tbk dengan hasil akhir berupa nilai akurasi prediksi harga pada saham. Diharapkan pada penelitian ini dapat memberi informasi sesuai dengan keaadan yang diinginkan. 
Halaman 250-256

available online at http://jom.fti.budiluhur.ac.id/index.php/IDEALIS/index

\section{METODE PENELITIAN}

\subsection{Metode CRISP-DM}

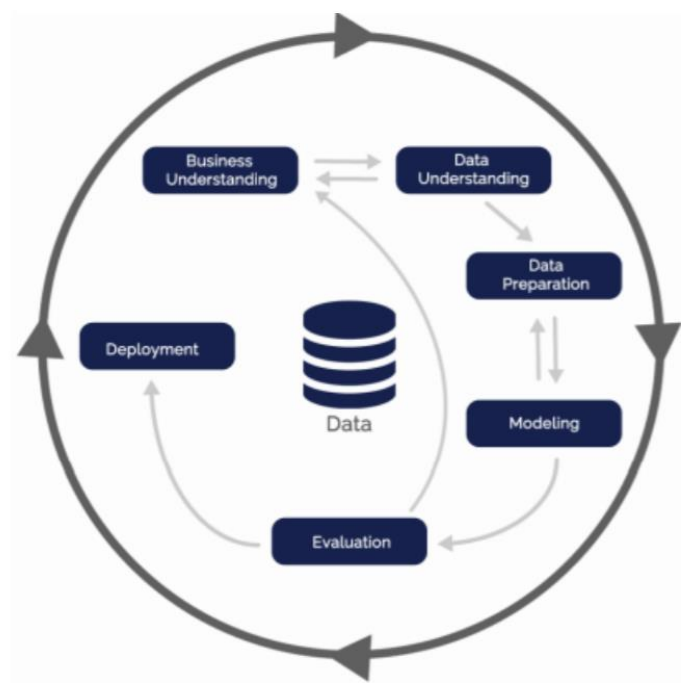

Gambar 1. Alur Proses CRISP-DM [12]

Gambar 1 diatas menggambarkan proses dalam metodologi CRISP-DM. Ada enam tahap berurutan yang dimulai dengan business understanding (pemahaman terhadap bisnis), data understanding (pemahaman terhadap data), data preparation (persiapan data), modeling (pemodelan), evaluation (evaluasi) dan deployment (penyebaran) [12].

\section{a. Pemahaman Terhadap Bisnis}

Penelitian dilakukan dengan tujuan untuk mendapatkan prediksi harga saham PT.Garuda Indonesia, Tbk dengan hasil akhir berupa akurasi prediksi harga saham dimana metode yang digunakan adalah metode algoritma Support Vector Machine (SVM) dengan menggunakan metode pembobotan CRISP-DM.

\section{b. Pemahaman Terhadap Data}

Penelitian yang dilakukan berdasarkan pada pergerakan saham harian PT.Garuda Indonesia, Tbk yang berupa data sekunder, terhitung mulai 18 Maret 2019 hingga 23 April 2021 menggunakan data historical yang diperoleh melalui website resmi yahoo finance. Data set yang digunakan telah dianalisa terlebih dahulu sehingga tidak memerlukan proses converting tipe data. Untuk mengurangi tingkat error dalam proses klasifikasi data, maka dilakukan cleaning dibeberapa nilai atribut yang tidak lengkap. Akan tetapi, penghapusan data atau baris tidak dilakukan untuk semua data salah satunya jika terdapat nilai nol pada atribut volume. Hal ini dikarenakan nol menjelaskan bahwa pada hari itu tidak terjadi transaksi jual beli saham. Data set ini terdiri atas 7 atribut yaitu Date, Dates_Time, Open, High, Low, Close dan Volume dengan total 520 data

\section{c. Persiapan Data}

Setelah pengolahan data dilakukan, data diklasifikan menjadi training dan testing. Dalam melakukan klasifikasi data menggunakan teknik Split Validation dengan masing-masing pembagian 78 data untuk data testing dan 442 data untuk data training. Kemudian kedua data akan diuji menggunakan metode SVM.

\section{d. Pemodelan}

Pada tahap modeling data yang telah dibagi akan diuji berdasarkan metode Support Vector Machine (SVM). Parameter yang digunakan C (cost) dan Kernel. Dimana proses dilanjutkan dengan dengan mencari nilai terbaik dari parameter tersebut.

\section{e. Evaluasi}

Pada tahap evaluasi ini, hasil uji data set yang sebelumnya telah dilakukan kemudian dievaluasi menggunakan Rapid Miner untuk melihat hasil tingkat akurasi trend prediksi dari pengujian menggunakan metode SVM untuk dataset dengan variabel (Date, Dates_Time, Open, High, Low, Close dan Volume). 
Halaman 250-256

available online at http://jom.fti.budiluhur.ac.id/index.php/IDEALIS/index

\section{f. Penyebaran}

Pada tahap keenam ini, pengetahuan atau informasi yang telah diperoleh akan diatur dan dipresentasikan dalam bentuk khusus sehingga dapat digunakan oleh pengguna.

\section{g. Metode SVM}

Pada tahap evaluasi ini, hasil uji data set yang sebelumnya telah dilakukan kemudian dievaluasi menggunakan Rapid Miner untuk melihat hasil tingkat akurasi trend prediksi dari pengujian menggunakan metode SVM untuk dataset dengan variabel (Date, Dates_Time, Open, High, Low, Close dan Volume).

\section{HASIL DAN PEMBAHASAN}

\subsection{Hasil Penelitian}

Dalam penelitian ini mempergunakan algoritma Support Vector Machine (SVM) dalam melakukan prediksi pergerakan saham PT. Garuda Indonesia, Tbk menggunakan data sekunder yaitu saham periode 18 Maret 2019 hingga 23 April 2021 sebanyak 520 dataset melalui proses training dan testing sehingga didapat hasil akurasi prediksi sebesar 0.545 sesuai dengan Gambar 2.

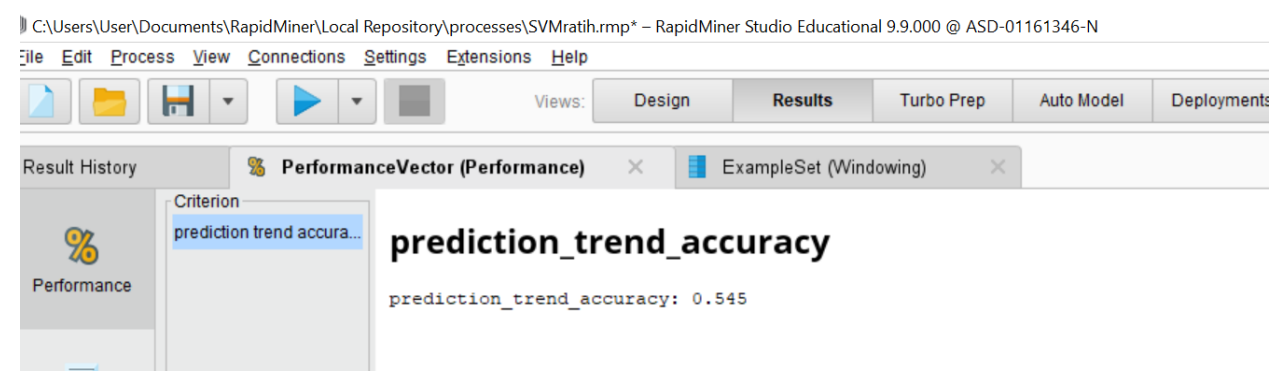

Gambar 2. Performance Prediction Trend Accuracy 520 Dataset Menggunakan Metode SVM

\subsection{Pembahasan}

a. Pemahaman Bisnis

Pada tahap pemahaman bisnis dilakukan kepada objek penelitian. Pada penelitian ini menggunakan data harian saham PT.Garuda Indonesia, Tbk yang diperoleh melalui website resmi yahoo finance. Pada tahapan pemahaman bisnis juga dilakukan untuk mencari metode yang digunakan untuk membantu saat proses mengolah data. Pada penelitian ini bertujuan mendapatkan prediksi harga saham menggunakan metode algoritma Support Vector Machine (SVM).

b. Pemahaman Data

Tahapan memahami data yang digunakan untuk penelitian. Berikut langkah-langkahnya. Menyiapkan data historical saham harian PT.Garuda Indonesia, Tbk yang diperoleh melalui website resmi yahoo finance. Data yang diperoleh sejumlah 520 data dengan periode mulai 18 Maret 2019 hingga 23 April 2021. Lalu dilakukan proses cleaning pada nilai atribut yang tidak lengkap. Akan tetapi, penghapusan data atau baris tidak dilakukan untuk semua data salah satunya jika terdapat nilai nol pada atribut volume. Hal ini dikarenakan nol menjelaskan bahwa pada hari itu tidak terjadi transaksi jual beli saham. Semua data disimpan dalam file dengan ektensi .csv.

\section{c. Persiapan Data}

Selanjutnya adalah tahapan persiapan data yang biasa disebut Data Preparation. Lalu data diklasifikasi menggunakan teknik Split Validation dengan masing-masing pembagian 78 data untuk data testing dan 442 data untuk data training.

\section{d. Pemodelan}

Tahapan ini merupakan tahap pemilihan algoritma yang akan digunakan. RapidMiner merupakan tool yang akan digunakan. Hasil pengujian yang dilakukan adalah prediksi harga saham PT.Garuda Indonesia, Tbk menggunakan algoritma Support Vector Machine (SVM) untuk memperoleh nilai akurasi. Berikut desain model RapidMiner yang digunakan. Pengaturan dan penggunaan parameter dalam RapidMiner yang akan berpengaruh terhadap akurasi dan model yang terbentuk. 
Halaman 250-256

available online at http://jom.fti.budiluhur.ac.id/index.php/IDEALIS/index

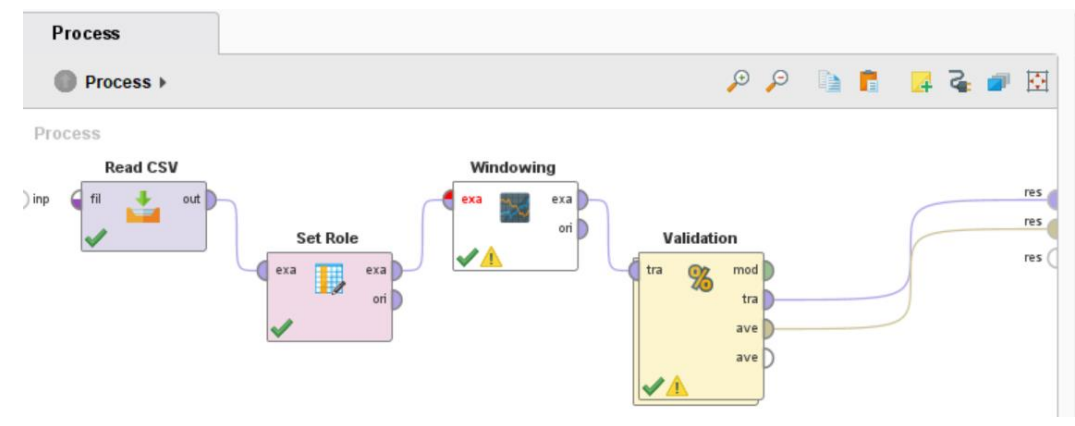

Gambar 3. Desain Process Pada Rapid Miner

Gambar 3 menjelaskan pengujian algoritma SVM menggunakan RapidMiner. Data diambil dengan menggunakan operator Read CSV, hal tersebut dikarenakan dataset disimpan dalam bentuk .csv lalu mengatur set role dengan menentukan Dates sebagai attribute dan Prediction sebagai target role. Kemudian mengatur windowing dengan series representation encode series by examples dan label attribute close, hal tersebut untuk memutuskan target yang diprediksi. Dilanjtukan dengan Set validation dengan training window width 442 , training window step size -1, test window width 78 dan horizon 1.

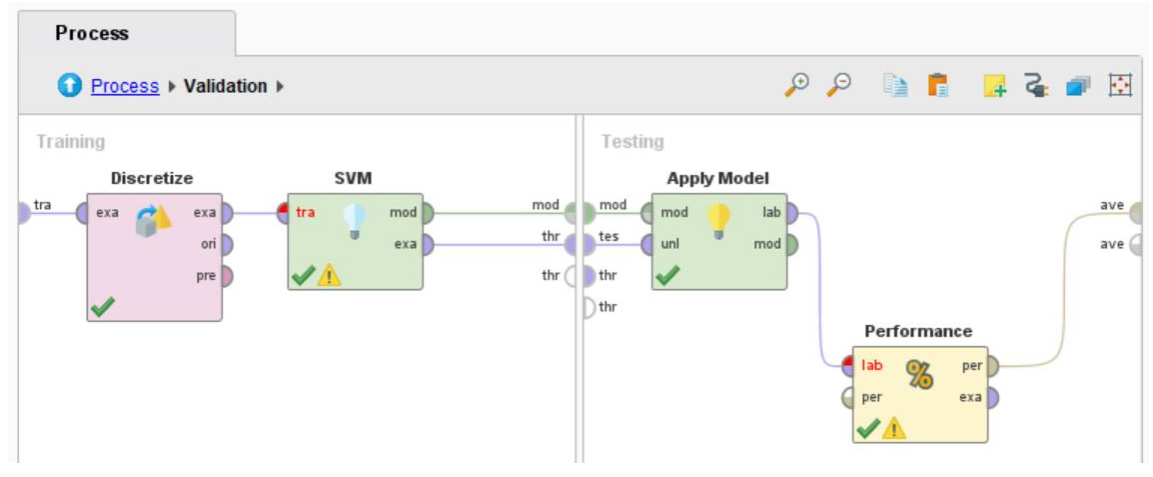

Gambar 4. Desain Process Validation Pada Rapid Miner

Gambar 4 menjelaskan desain di dalam operator validation. Model SVM yang digunakan lalu set kernel type radial, kernel gamma 1.0, intertia weight 0.1 local best weight 1.0 global best weight 1.0. Kemudian apply model dan performance maka akan terdapat hasil nilai accuracy.

e. Evaluasi

Evaluasi memiliki tujuan menentukan nilai kegunaan model yang telah dibuat dengan langkah-langkah sebelumnya.

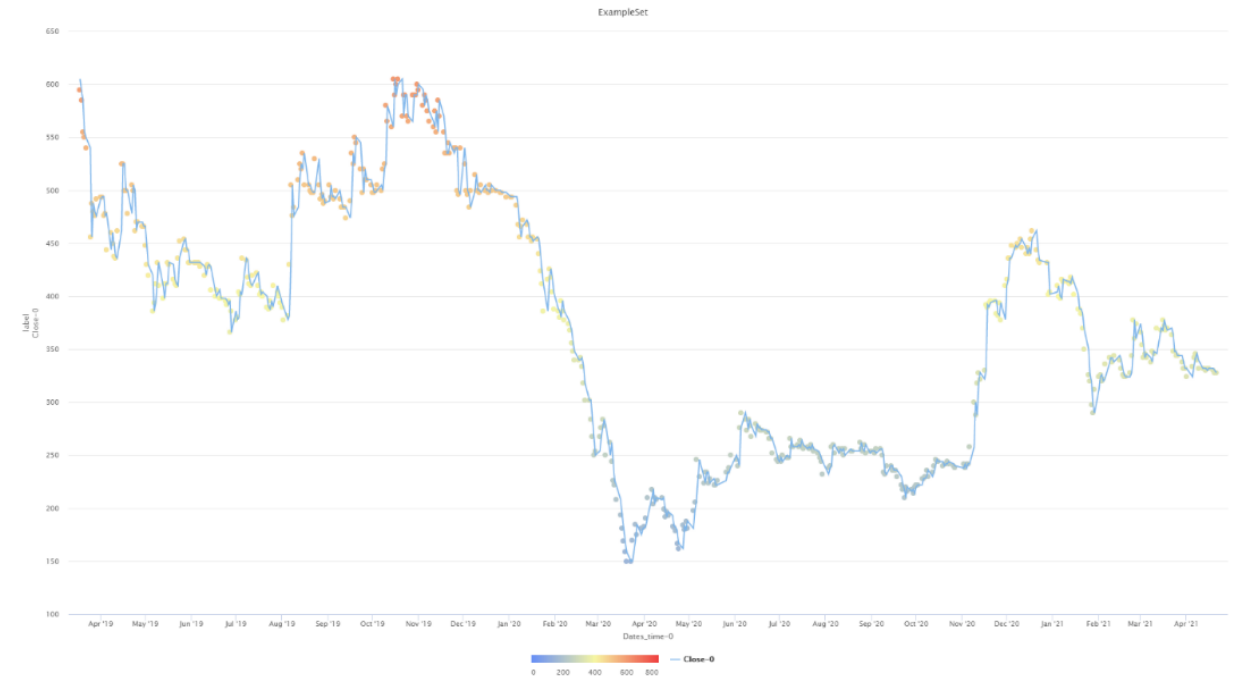


Halaman 250-256

available online at http://jom.fti.budiluhur.ac.id/index.php/IDEALIS/index

Gambar 5. Example Set Grafik Trend Accuracy Prediksi Menggunakan Metode SVM

Pada Gambar 5 merupakan visualisasi hasil Prediksi trend accuracy. Untuk plot type line berwarna biru merupakan harga penutupan yang sebenarnya. Untuk plot type scatter / bubble dengan beberapa warna merupakan prediksi harga penutupan.

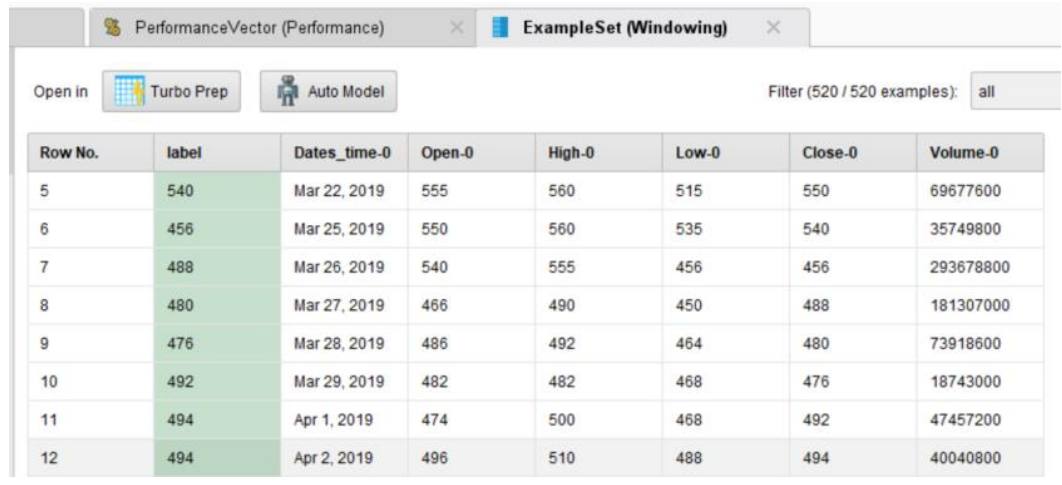

Gambar 6. Example Set Data Trend Accuracy Menggunakan Metode SVM

Pada Gambar 6 merupakan data hasil Prediksi trend accuracy. Dimana pada kolom label merupakan prediksi harga penutupan yang dihasilkan dengan menggunakan metode SVM. Pada tanggal 01 April 2019 prediksi harga yang dihasilkan untuk harga penutupan sebesar 494 rupiah namun harga penutupan sesungguhnya pada tanggal tersebut sebesar 492 rupiah, sehingga prediksi harga penutupan memiliki selisih 2 rupiah antara harga prediksi dan harga sesungguhnya. Pada tanggal 02 April 2019 menghasilkan prediksi harga penutupan yang sama denga harga sebenernya yaitu sebesar 494 rupiah, sehingga tidak terdapat selisih harga antara harga prediksi dan harga sesungguhnya.

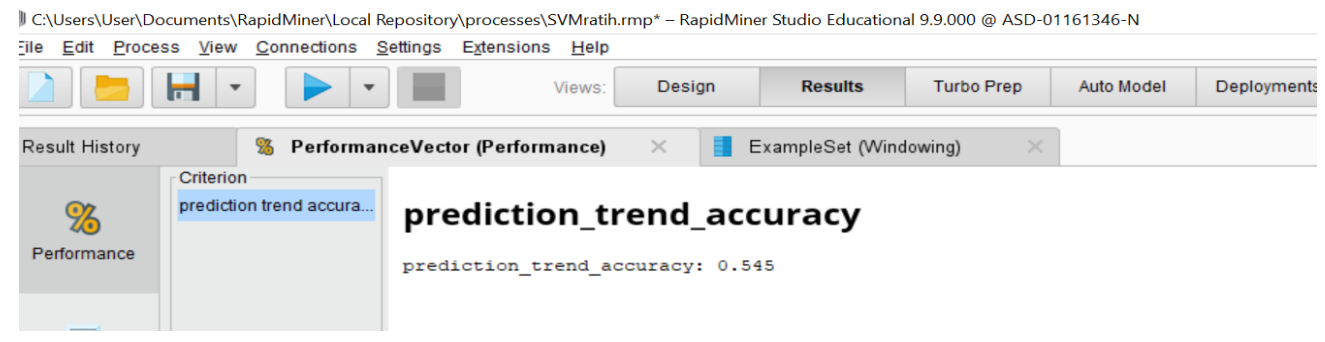

Gambar 7. Performance Prediction Trend Accuracy Menggunakan Model SVM

Pada Gambar 7 merupakan hasil dari pengujian model SVM yang menghasilkan performance prediction trend accuracy sebesar 0.545 dengan menggunakan 520 dataset dan dengan hasil nilai trend akurasi prediksi tersebut berarti SVM dapat digunakan sebagai model untuk memprediksi harga saham penutupan pada PT. Garuda Indonesia, Tbk.

\section{KESIMPULAN}

Penelitian dilakukan dengan menggunakan metode Support Vector Machine (SVM) dalam melakukan prediksi terkait harga saham PT. Garuda Indonesia, Tbk dengan menggunakan data historical yang diperoleh melalui website resmi yahoo finance pada periode 18 Maret 2019 hingga 23 April 2021 dengan rincian atribute Date, Dates_Time, Open, High, Low, Close dan Volume. Dalam penelitian ini melalui proses training dan testing diketahui bahwa hasil akurasi prediksi sebesar 0.545 dengan menggunakan 520 dataset dan dengan hasil nilai trend akurasi prediksi tersebut berarti Support Vector Machine (SVM) dapat digunakan sebagai model untuk memprediksi harga saham penutupan pada PT. Garuda Indonesia, Tbk. Dengan adanya model prediksi harga saham PT.Garuda Indonesia, Tbk menggunakan SVM maka dapat membantu investor untuk menentukan langkah dalam bertransaksi saham.

Pada penelitian selanjutnya yang perlu penulis sarankan yaitu diharapkan penelitian berikutnya hasil trend akurasi dapat ditingkatkan dengan memanfaatkan metode yang berbeda serta dapat menggunakan dataset yang lebih banyak dan bervariasi. Sehingga diharapkan terjadi peningkatan trend akurasi untuk melakukan prediksi harga saham. 
INDONESIA JOURNAL INFORMATION SYSTEM (IDEALIS)

Volume 4, Nomor 2, Bulan 2021

ISSN 2684-7280 (online)

Halaman 250-256

available online at http://jom.fti.budiluhur.ac.id/index.php/IDEALIS/index

\section{DAFTAR PUSTAKA}

[1] Bursa Efek Indonesia, "Produk: Saham”, [Online] Available: https://www.idx.co.id/produk/saham/ [diakses May 09, 2021].

[2] W. Y. Rusyida, and V. Y. Pratama, "Prediksi Harga Saham Garuda Indonesia di Tengah Pandemi Covid-19 Menggunakan Metode ARIMA", SQUARE: Journal of Mathematics and Mathematics Education, vol. 2, no. 1, pp. 73-81, 2020.

[3] A. B. Untoro, "Prediksi Harga Saham Dengan Menggunakan Jaringan Syaraf Tiruan”, Jurnal Teknologi Informatika dan Komputer MH Thamrin, vol. 6, no. 2, pp.103-111, 2020.

[4] V. G. Utomo, N. Wakhidah, and A. N. Putri, "Prediksi Harga Saham Dengan Svm (Support Vector Machine) dan Pemilihan Fitur FScore", Jurnal Informatika Upgris (JIU), vol. 6, no. 1, pp. 32-37, 2020.

[5] V. Rusmalawati, M. Tanzil Furqon, and I. Indriati, "Peramalan Harga Saham Menggunakan Metode Support Vector Regression (SVR) Dengan Particle Swarm Optimization (PSO)", JPTIIK, vol. 2, no. 5, pp. 1980-1990, 2018.

[6] Y. Ramdhani and A. Mubarok, "Analisis Time Series Prediksi Penutupan Harga Saham ANTM. JK Dengan Algoritma SVM Model Regresi”, Jurnal Responsif, vol. 1, no. 1, pp. 77-82, 2019.

[7] R. H. Kusumodestoni, and S. Sarwido, "Komparasi Model Support Vector Machines (SVM) dan Neural Network Untuk Mengetahui Tingkat Akurasi Prediksi Tertinggi Harga Saham”, Jurnal Informatika Upgris (JIU), vol. 3, no. 1, pp.1-8, 2017.

[8] W. R. U. Fadilah, D. Agfiannisa, and Y. Azhar, "Analisis Prediksi Harga Saham PT. Telekomunikasi Indonesia Menggunakan Metode Support Vector Machine," Fountain of Informatics Journal, vol. 5, no. 2, pp. 45, 2020.

[9] E. Patriya, "Implementasi Support Vector Machine Pada Prediksi Harga Saham Gabungan (IHSG)," Jurnal Ilmiah Teknologi dan Rekayasa, vol. 25, no. 1, pp. 24-38, 2020.

[10] F. R. Setiawan, R. F. Umbara, and A.A. Rohmawati, "Prediksi Pergerakan Harga Saham dengan Metode Support Vector Machine (SVM) Menggunakan Trend Deterministic Data Preparation”, e-Proxeeding of Engineering, vol. 5m no. 3, pp.8356-8372, 2018.

[11] A. S. Nugroho, A. B. Witarto, and D. Handoko, "Support Vector Machine-Teori dan Aplikasinya dalam Bioinformatika 1" 2003. [Online]. Available: http://asnugroho.net

[12] Y. Suhanda, I. Kurniati, and S. Norma, "Penerapan Metode Crisp-DM Dengan Algoritma K-Means Clustering Untuk Segmentasi Mahasiswa Berdasarkan Kualitas Akademik", Jurnal Teknologi Informatika dan Komputer MH Thamrin, vol. 6, no. 2, pp. 12-20, 2020. 